NIST Special Publication 1241

\title{
Large Outdoor Fires and the Built Environment (LOF\&BE): Summary of Workshop at Interflam 2019
}

Sponsored by the International Association for Fire Safety Science (IAFSS)

Samuel L. Manzello Sara McAllister Sayaka Suzuki Raphaele Blanchi

Elsa Pastor Enrico Ronchi

This publication is available free of charge from: https://doi.org/10.6028/NIST.SP.1241

THE INTERNATIONAL ASSOCIATION FOR FIRE SAFETY SCIENCE

National Institute of Standards and Technology U.S. Department of Commerce 


\section{Large Outdoor Fires and the Built Environment (LOF\&BE): Summary of Workshop at Interflam 2019}

Samuel L. Manzello

Fire Research Division, Engineering Laboratory

Sara McAllister

U.S. Forest Service, U.S. Department of Agriculture, Missoula, MT USA

Sayaka Suzuki

National Research Institute of Fire and Disaster, Chofu, Tokyo, Japan

Raphaele Blanchi

Commonwealth Scientific and Industrial Research Organization, Melbourne, Australia

Elsa Pastor

Universitat Politècnica de Catalunya, Barcelona, Spain

Enrico Ronchi

Lund University, Lund, Sweden

This publication is available free of charge from:

https://doi.org/10.6028/NIST.SP.1241

August 2019

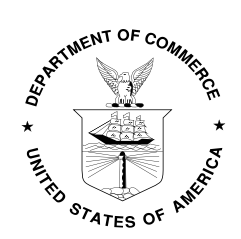

U.S. Department of Commerce

Wilbur L. Ross, Jr., Secretary

National Institute of Standards and Technology Walter Copan, NIST Director and Under Secretary of Commerce for Standards and Technology 
Certain commercial entities, equipment, or materials may be identified in this document in order to describe an experimental procedure or concept adequately. Such identification is not intended to imply recommendation or endorsement by the National Institute of Standards and Technology, nor is it intended to imply that the entities, materials, or equipment are necessarily the best available for the purpose.

The content of the oral presentations reproduced in this workshop report are those of the authors and do not necessarily represent NIST's perspective.

National Institute of Standards and Technology Special Publication 1241

Natl. Inst. Stand. Technol. Spec. Publ. 1241, 21 pages (August 2019)

CODEN: NSPUE2

This publication is available free of charge from: https://doi.org/10.6028/NIST.SP.1241 


\begin{abstract}
A workshop of the permanent working group, sponsored by the International Association for Fire Safety Science (IAFSS), entitled Large Outdoor Fires and the Built Environment (LOF\&BE) was held from 2:00 pm to 4:00 pm on Sunday June 30, 2019. The workshop was held as a part of the 2019 Interflam Conference in Egham, United Kingdom. The working group is co-led by Sara McAllister of the U.S. Forest Service, Sayaka Suzuki of the National Research Institute of Fire and Disaster, and Samuel L. Manzello of NIST's Engineering Laboratory. The IAFSS permanent working group consists of three subgroups, with subleaders appointed by Manzello, McAllister, and Suzuki, and these are prioritized into the following topics: Ignition Resistant Communities (IRC - led by Elsa Pastor, UPC), Emergency Management and Evacuation (EME, led by Enrico Ronchi, Lund University), and Large Outdoor Firefighting (LOFF, led by Raphaele Blanchi, CSIRO, unable to travel to UK). The IRC subgroup is focused on developing the scientific basis for new standard testing methodologies indicative of large outdoor fire exposures, including the development of necessary testing methodologies to characterize wildland fuel treatments adjacent to communities. The EME subgroup is focused on developing the scientific basis for effective emergency management strategies for communities exposed to large outdoor fires. The LOFF subgroup is providing a review of various tactics that are used, as well as the various personal protective equipment (PPE), and suggests pathways for research community engagement, including environmental issues in suppressing these fires. At the workshop, detailed progress was presented regarding activities of all the subgroups. An extended session was held for open discussion so that participants could provide feedback on current progress and offer suggestions for the upcoming LOF\&BE workshop being organized as part of IAFSS 2020.
\end{abstract}

\title{
Key words
}

Large Outdoor Fires; Urban Fires; Wildland-Urban Interface (WUI) Fires; Informal Settlement Fires; Wildland Fires 


\section{Table of Contents}

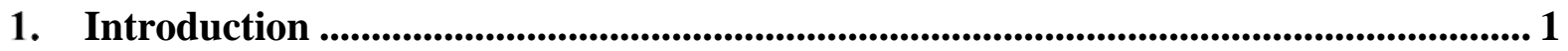

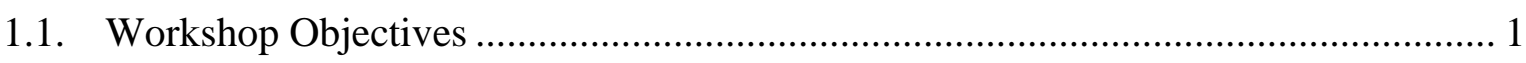

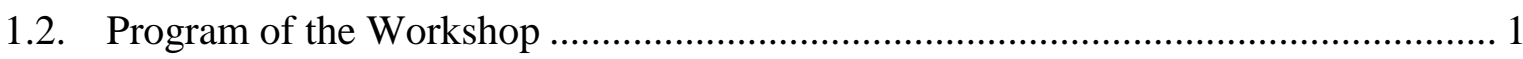

1.3. List of Registered Participants (Alphabetical Order) ............................................ 1

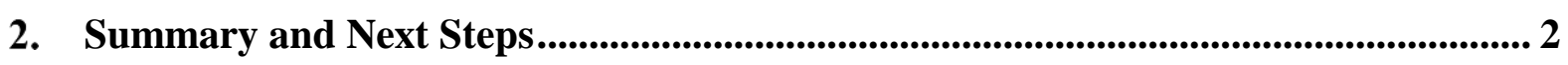

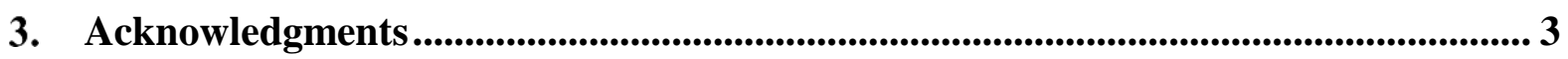

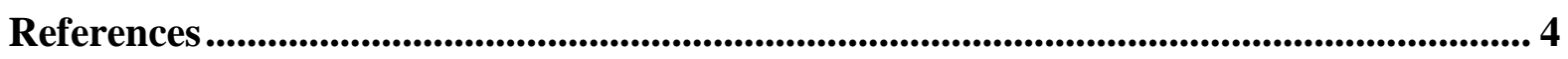

Appendix A: Presentations Delivered at the Workshop ................................................ 5 


\section{Introduction}

\subsection{Workshop Objectives}

The International Association for Fire Safety Science (IAFSS) has approved the formation of the permanent working group entitled Large Outdoor Fires and the Built Environment or (LOF\&BE) [1]. This report details the second official workshop of this permanent working group. The workshop at Interflam 2019 was organized as a unique partnership between IAFSS and Interflam, the two largest conferences focused on fire safety science.

\subsection{Program of the Workshop}

\begin{tabular}{|c|c|c|}
\hline Time & Title & Speaker \\
\hline $2: 00-2: 15$ & Introduction & $\begin{array}{c}\text { S. Manzello*, S. } \\
\text { McAllister, S. Suzuki* }\end{array}$ \\
\hline $2: 15-2: 30$ & LOFF & R. Blanchi/S. McAllister* \\
\hline $2: 30-2: 45$ & IRC & E. Pastor \\
\hline $2: 45-3: 00$ & EME & E. Ronchi \\
\hline $3: 00-4: 00$ & Open Discussion & All participants \\
\hline
\end{tabular}

*denotes speaker

\subsection{List of Registered Participants (Alphabetical Order by Surname)}

Danielle Antonellis (Arup, UK)

Gaurav Agarwal (FM Global, USA)

Mohamed Beshir (University of Edinburgh, UK)

Nelson Bryner (National Institute of Standards and Technology, USA)

Mike Burroughs (Fire Investigation, UK)

Alexandra Bystrom (Lulea University of Technology, Sweden)

Piergiacomo Cancelliere (Italian National Fire and Rescue Service, Italy)

René Champagne (Parks Canada/York University, Canada)

Giovanni Cocchi (Arson S.R.I., Italy)

Bernard Cosh (Cosh Fire Safety, UK)

Ryan Falkenstein-Smith ((National Institute of Standards and Technology, USA)

Ragni Fjellgaard Mikalsen (RISE Fire Research, Sweden)

Merlyn Ferrer (Design Fire Consultants, UK)

Justin Francis (Queensland Fire and Emergency Services, Australia)

John Gales (York University, Canada)

Richard Gann (AGANNstFire, USA)

Islaam Gomaa (National Research Council Canada, Canada)

Mark Gratkowski (Bureau of Alcohol, Tobacco, Firearms \& Explosives, USA)

Steve Gwynne (Movement Strategies, UK)

Tuula Hakkarainen (VTT Technical Research Centre of Finland, Finland)

Testuya Hayakawa (TSV, Japan)

Faraz Hedayati (Insurance Institute for Business \& Home Safety, USA)

Marcelo Hirschler (GBH International, USA)

Robert Jannson McNamee (Brandskyddslaget, Sweden)

Geir Jensen (Securo AS, Norway)

Amanda Kimball (Fire Protection Research Foundation/NFPA, USA)

Egor Kuznetov (Peter the Great Saint Petersburg Polytechnic University, Russia)

Susan Lamont (Arup, UAE) 
Brian Lattimer (Virginia Tech, USA)

Isaac Leventon (National Institute of Standards and Technology, USA)

Johanna Liblik (Tallinn University of Technology, Estonia)

Andrew Lock (U.S. Consumer Products Safety Commission, USA)

Samuel L. Manzello (National Institute of Standards and Technology, USA/Japan)

Frank Markert (Denmark Technical University, Denmark)

Ekaterina Markus (Peter the Great Saint Petersburg Polytechnic University, Russia)

Bertrand Mathy (AGC Glass Europe, Belgium)

Sara McAllister (USDA Forest Service, USA)

Margaret McNamee (Lund University, Sweden)

Harry Mitchell (Imperial College London, UK)

Elsa Pastor (Universitat Politècnica de Catalunya, Spain)

Jake Pauls (Jake Pauls Consulting, USA)

Hugues Pretel (Institut de Radio Protection et de Sûreté Nucléaire, France)

Chandler Probert (North Carolina State University, USA)

Vincenzo Puccia (Corpo Nazionale dei Vigili del Fuoco, Italy)

Guillaume Rambaud (Commissariat à l'Énergie Atomique et aux Énergies Alternatives, France)

Lindsay Ranger (FP Innovations, Canada)

Enrico Ronchi (Lund University, Sweden)

David Rush (University of Edinburgh, UK)

Adhiraj Shinde (North Carolina State University, USA)

Pitor Smardz (INBEPO, Poland)

Anne Steen-Hanson (RISE Fire Research, Norway)

Sayaka Suzuki (National Research Institute of Fire and Disaster, Japan)

Jean-Baptiste Tramoni (Centre Technique Industriel De La Construction Metallique, France)

Juergen Troiroseh (Troiroseh Company, Switzerland)

Patrick van Hees (Lund University, Sweden)

Yi Wang (FM Global, USA)

Alex Webb (Commonwealth Scientific and Industrial Research Organization, Australia)

Jennifer Wen (Warwick University UK)

Yuki Yamauchi (Railway Technical Research Institute, Japan)

Hideki Yoshioka (National Institute for Land and Infrastructure Management, Japan)

\section{Summary and Next Steps}

A total of 60 global experts participated, representing institutions from Australia, Belgium, Canada, Denmark, Estonia, France, Finland, Italy, Japan, Norway, Poland, Russia, Spain, Sweden, Switzerland, United Kingdom, United Arab Emirates, and USA. The workshop began with an introductory presentation that explained what is LOF\&BE, the objectives, and the overall direction and focus of the group.

LOF\&BE is divided into three main approaches. Specifically, Phase 1 is the data collection aspect where each of the three subgroups are collecting all available information on codes and standards, best practices, and current research for their respective topic areas. In Phase 2 , each subgroup will attempt to identify the gaps amongst codes and standards, between codes and standards and current research, and within current research. In the final Phase, called Phase 3, each subgroup will work on products to address the identified gaps. 
At present, all three subgroups are still working in Phase 1, so the audience was queried as to the progress that each subgroup is achieving to this end. It was also decided by the LOF\&BE team to open up the floor for a free flowing discussion.

The following is a list of key discussion points:

- Suggestions on getting the research community more involved with Codes and Standards. How to actually do this?

- How to incorporate informal settlement fires into IRC and LOFF subgroups? An important safety issue for informal settlement fires is that firefighters need to be able to cope with the collapse of sections of the entire settlements.

- Firefighters' involvement on personal protective equipment (PPE) is necessary.

- Emissions from burning vegetation and structures are different at different stages. Understanding the details as well as overview are important.

- More interaction and attendance from the fire service is needed at important international conferences focused exclusively on fire safety science, such as Interflam and IAFSS. How to actually have better interaction?

- A sociological prospective is needed for EME group.

- Questions on involvements with standard bodies. ISO TC92 has developed a specific working group (WG): ISO TC92/WG14 (Large Outdoor Fires and the Built Environment). Important research findings as part of the IAFSS LOF\&BE effort will be constantly shared with the ISO TC9/WG14 activity. This is easier, as Dr. Manzello is the convener of the ISO TC92/WG14. More cross-cutting activities into other standards bodies, work is needed outside ISO TC92.

- It is important to get industry involved, construction companies and insurance companies. As in most cases, cost is really the driving factor for change.

- Simple description on what are some key work items needed in each group. In this way, the community would be in a better positon to help the overall LOF\&BE effort. A specific suggestion included a list of potential projects that final year students could work on.

The LOF\&BE team plan to use these valuable suggestions going forward. In particular, these will be most helpful as the next workshop is prepared as part of the IAFSS 2020 meeting to be held in Waterloo, Canada.

\section{Acknowledgments}

The support of the organizing committee of the 2019 Interflam Conference is greatly appreciated. In particular, the authors wish to acknowledge the help of Dr. Stephen Grayson 
(Interscience Communications; Interflam Conference Chair), Ms. Sue Wolf (Interscience Communications, UK), and Ms. Teri-Leigh Peach (Fire Testing Technology, UK). The LOF\&BE team would also like to personally thank Professor Patrick Van Hees of Lund University, IAFSS President for his constant support. SLM would like to thank both Drs. Grayson and Van Hees for making the integration of the IAFSS LOF\&BE effort into Interflam 2019 as seamless as possible.

\section{References}

[1] Manzello, S.L., McAllister, S., Suzuki, S., Blanchi, R., Pastor, E., and Ronchi, E., (2019) Large Outdoor Fires and the Built Environment: Summary of Kick-off Workshop, NIST Special Publication 1236 https://doi.org/10.6028/NIST.SP.1236. 
Appendix A: Presentations Delivered at the Workshop 

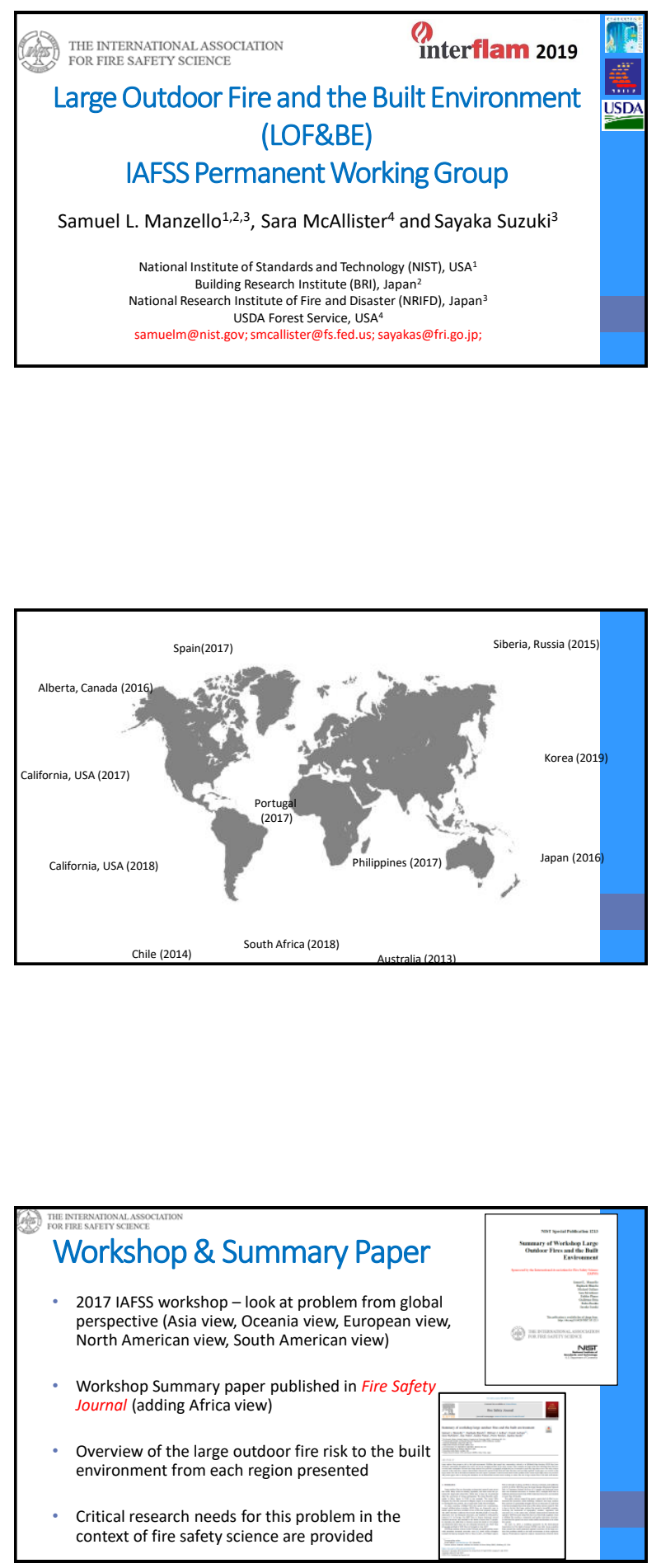

\section{What LOF\&BE means?}
Large Outdoor Fires and the Built Environment (LOF\&BE)

Wildland fires (or forest fires)*, wildland-urban interface (WUI) fires, urban fires**, and informal settlement fires, which pose a threat to people

** Urban fires include post-earthquake fires

\section{Introduction}

- Over the past several decades, fire safety science research has spent a great deal of effort to understand fire dynamics within buildings

- Research into large outdoor fires, and how to potentially mitigate the loss of structures in such fires, lags behind other areas of fire safety science research

- Large outdoor fires affect many people in the world directly and indirectly, both short term and long term (e.g. evacuation, losing property, losing loved ones, breathing products of combustion)

\section{Some Important Problems?}

- Fire spread in Large Outdoor fires

- Very complex - interaction of topography, weather, vegetation, and structures - Structure-structure fire spread can occur under similar mechanisms as in urban fire spread as well as WUI fire spread

- Impact on fire and smoke on climate and health

- Long term and short term effect

- Large outdoor firefighting

- Structure/Urban firefighting PPE and tactics different than wildland fire firefighting PPE and tactics; what needs to be done for WUI fire fighting?

- Emergency management strategies

- How or when or whether to evacuate 


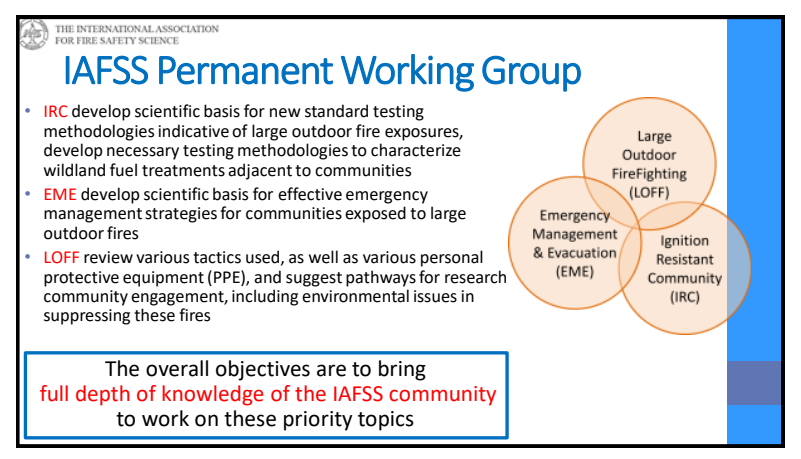

\section{IAFSS 2020 Plans}

- LOF\&BE workshop

-WG (sub-groups)' efforts on Phase 1 will be presented

- We hope to get feedback from you! (which we call a part of Phase 2)

If you would like to join WG, please sign up from the link below or QR codes; https://goo.gl/forms/0TMW2SbWi7mmHYlv1

\section{General Approach}

- Phase 1 Collect information

- Codes and standards

- Best practices

- Current research

- Phase 2 Identify the 'Gaps'

- Among codes and standards

- Among codes and standards and current research

- Among current research

- Phase 3 Work on 'Products' solving the Gaps

\section{Acknowledgement}

- All the WG members

\section{interflam 2019}

THE INTERNATIONAL ASSOCIATION FOR FIRE SAFETY SCIENCE

\section{Program}

Time: June $20^{\text {th }} 2019$ (Sun) 2 PM - 4 PM

Location: $1^{\text {st }}$ Floor at Windsor Building

\begin{tabular}{|l|l|l|}
\hline Time & Title & Speaker \\
\hline 2:00-2:15 & Introduction & $\begin{array}{l}\text { S. Manzello, S. McAllister, S. } \\
\text { Suzuki }\end{array}$ \\
\hline 2:15-2:30 & LOFF & R. Blanchi / S. McAllister \\
\hline $2: 30-2: 45$ & IRC & E. Pastor \\
\hline 2:45-3:00 & EME & E. Ronchi \\
\hline $3: 00-4: 00$ & Open Discussion & All participants \\
\hline
\end{tabular}




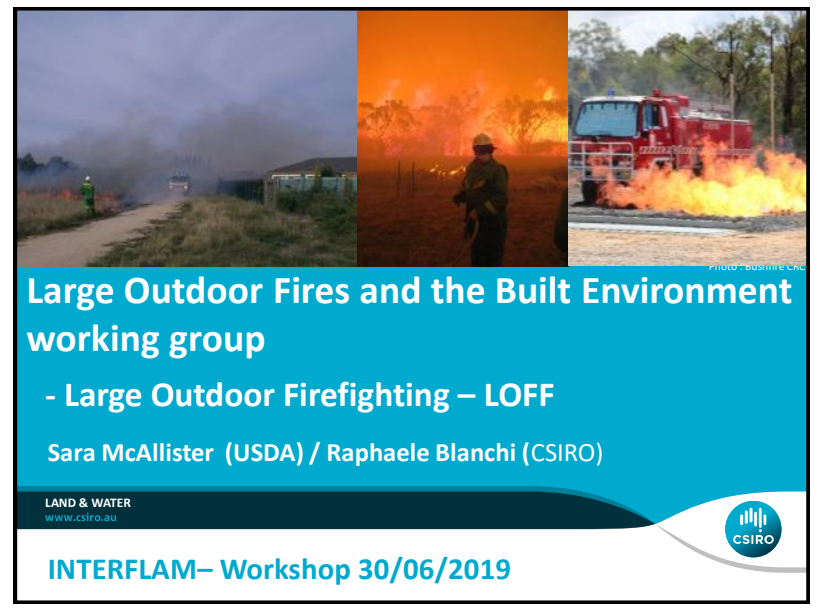

\section{Type of firefighters survey}

- Survey : 37 persons from 16 countries

\begin{tabular}{|c|c|}
\hline Type of firefighters & Number of countries \\
\hline $\begin{array}{l}1 \text { type of firefighters: Firefighters work for both urban } \\
\text { and wildland (or forest) fires }\end{array}$ & 11 \\
\hline $\begin{array}{l}2 \text { types of firefighters: Structure firefighters (who work } \\
\text { for urban fires) and wildland firefighters (who works for } \\
\text { wildland or forest fires) }\end{array}$ & 5 \\
\hline $\begin{array}{l}3 \text { types of firefighters: Structure firefighters, wildland } \\
\text { firefighters, and WUI firefighters }\end{array}$ & 0 \\
\hline \multicolumn{2}{|c|}{$\begin{array}{l}\text { We would like to thanks Anthony Collin, Ashruf Syed, Amjid hussein Gulamhussein, } \\
\text { Sébastien Lahaye, Guillermo Rein, Alex Filkov, Faraz Hedayati, Luís Mario Ribeiro, Daniel } \\
\text { Gorham, Hubert Biteau, Len Garis, Adi Putra, Darlene Rini, Dionysios Kolaitis, Ya-Ting T. } \\
\text { Liao, Kuibin, Gordon Anderson, Ryan Falkenstein-Smith, Eric Link, Juan Antonio Muñoz, } \\
\text { Elsa Pastor, Nuria Prat-Guitart, Xinyan Huang, Yu Wang, Enrico Ronchi and all the other } \\
\text { members that have replied to the survey }\end{array}$} \\
\hline
\end{tabular}

\section{Protection of firefighters - PPE}

\section{Background}

- Protection of firefighter is an important aspect of firefighter safety in wildland fire, urban fire and WUI fire where both the wildlands and the structures are involved

\section{Objectives}

- Develop a framework for this new combined wildland/structure fire exposure, to assess PPE requirements

- Establish a network between fire researchers and fire managers for discussion and exchange

How?

$\checkmark$ Develop a repository for inventories of PPE (both international and local Standards)

\section{Large Outdoor Firefighting - LOFF}

- General aim

To develop the scientific basis for wildland/WUI fires/urban fires firefighter safety. First, including personal protective equipment (PPE), health and environmental issues in suppressing these fires. Later, various Firefighting tactics that are used, pathways for research community engagement.

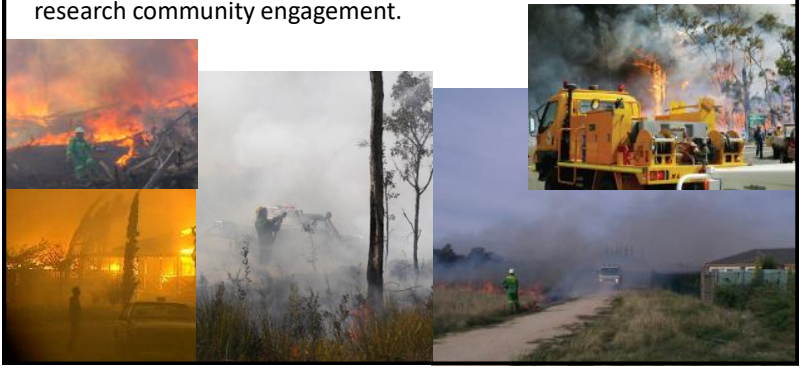

\section{Summary firefighters survey by countries}

\begin{tabular}{|c|c|c|c|}
\hline Countries & $\begin{array}{l}\text { Only one kind - our } \\
\text { firefighters work for both } \\
\text { urban and wildland (or } \\
\text { forest) fires }\end{array}$ & $\begin{array}{l}\text { Structure firefighter (who work } \\
\text { for urban fires) and wildland } \\
\text { firefighters (who works for } \\
\text { wildland or forest fires) }\end{array}$ & $\begin{array}{l}\text { Structure firefighter, } \\
\text { wildland firefighter, and } \\
\text { wUI firefighter }\end{array}$ \\
\hline Australia & & $\mathrm{x}$ & \\
\hline Canada & & $\mathrm{x}$ & \\
\hline China & & $\mathrm{x}$ & \\
\hline France & $\mathrm{x}$ & & \\
\hline Greece & $\mathrm{x}$ & & \\
\hline Indonesia & $\mathrm{x}$ & & \\
\hline India & $\mathrm{x}$ & & \\
\hline Israel & $x$ & & \\
\hline Japan & $\mathrm{x}$ & & \\
\hline Kenya & $\mathrm{x}$ & & \\
\hline Malaysia & $\mathrm{x}$ & & \\
\hline Portugal & $\mathrm{x}$ & & \\
\hline Spain & & $\mathrm{x}$ & \\
\hline Sweden & $\mathrm{x}$ & & \\
\hline United Kingdom & $\mathrm{x}$ & & \\
\hline USA & & $x$ & \\
\hline
\end{tabular}

\section{Progress PPE}

- Depend on country : Structure FF only or Wildland and Structure FF

- Plethora of regulations and Standards

\begin{tabular}{|c|c|c|}
\hline Type of fires & PPE objectives & Standards/guidelines (example) \\
\hline Wildland fire & $\begin{array}{l}\text { Protect from low to medium fire } \\
\text { exposure } \\
\text { L Long shift and hard work } \\
\text { Need: } \\
\text { - } \rightarrow \text { Adequate protection to reduce } \\
\text { the exposure to heat and adequate } \\
\text { ventilation to reduce heat stress } \\
\rightarrow>\text { Protection from injury }\end{array}$ & $\begin{array}{l}\text { International Standards Organization (ISO) - PPE (ISO/DIS 16073- } \\
\text { 1) under development } \\
\text { ISO TC94 SC14 (21 Standards on Firefighters' personal } \\
\text { equipment) } \\
\text { Europe: EN 15614:2007, Protective clothing for firefighters } \\
\text { USA : NFPA 1977, Standard on Protective Clothing and Equipment } \\
\text { for Wildand fire Fighting, } 2016 \text { current Edition }\end{array}$ \\
\hline Urban fires & $\begin{array}{l}\text { Protect from high thermal } \\
\text { exposure (flame and excessive } \\
\text { heat) } \\
\text { Need: } \\
\text {->Adequate protection and } \\
\text { ventilation } \\
\text {->Protect from injury } \\
\text {->Protect from smoke (toxic gas) } \\
\text {->Protect from liquid/chemicals }\end{array}$ & 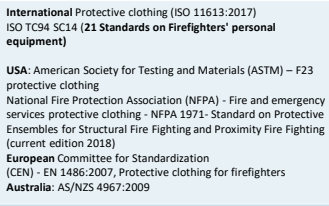 \\
\hline WUI fires & -Protect from mixed exposure & $\begin{array}{l}\text { CAL FIRE Wildland Urban Interface Book and } \\
\text { Operating Principles Book }\end{array}$ \\
\hline
\end{tabular}




\section{Research on firefighter PPE (wildland and urban fire)}

- Research on textile resistant to flame, ventilation physiology and heat management

- Right balance between thermal protection and reducing heat stress and optimum comfort (eg McQuerry et al. 2015)

- Textile characteristics (e.g. wildland fire fighters)

- Radiative Protective Performance (resistance to flame, radiation): reasonable maximum exposure around 7kW/m2 (NFPA 1977 revised)

- Total Heat Loss (ventilation): 450 watts per square meter (W/m2 ) (NFPA 1977)

- Other considerations:

- Strength, resist penetration by liquid, visibility

- Performance, weight, ergonomy,

design, durability, flexibility

- Care/Maintenance

- Helmet, gloves, boot, face mask

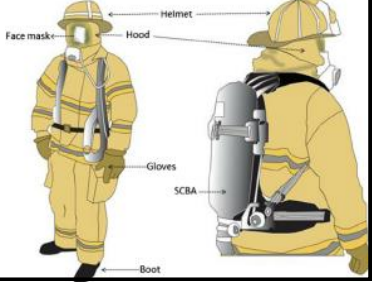

\section{Progress health - smoke exposure}

\begin{tabular}{|c|c|c|}
\hline $\begin{array}{l}\text { Type of } \\
\text { fires }\end{array}$ & Smoke exposure and health effect & Studies examples \\
\hline $\begin{array}{l}\text { Wildland } \\
\text { fire }\end{array}$ & $\begin{array}{l}\text { Smoke exposure depend on: } \\
\text {-Fire and fuels characteristics (wildland fuels) } \\
\text {-Duration and intensity of fires } \\
\text {-Smoke distribution (wind and topography) } \\
\text {-Pollutants, example: } \\
\text { C Carbon monoxide } \\
\text { - Respirable particles } \\
\text { - Aldehydes } \\
\text { vocs } \\
\text { Health effects: } \\
\rightarrow \rightarrow \text { Short term } \\
\rightarrow \text { Long term effect }\end{array}$ & $\begin{array}{l}\text { Australia: } \\
\text { Measurement of firefigter exposure to bushfire and } \\
\text { prescribed burning smoke: } \\
\text { E.g. Reisen, F., \& Brown, S. K. (2009) Reisen et al. (2011) } \\
\text { Mediterranean Europe: Characterising the health effects } \\
\text { (long-term and short-term) of the exposure to fire smoke } \\
\text { in firefighters that perform prescribed burns. Aldea et al. } \\
\text { France: } \\
\text { Smoke exposure of firefighters during prescribed burning } \\
\text { E.g. Lahaye (2011); Barboni et al. (2010) } \\
\text { UsA: } \\
\text { Review of the health effects of wildland fire smoke on } \\
\text { wildland firefighters: Adetona et al. (2016) } \\
\text { Measurements of smoke exposure among wildland } \\
\text { firefighters: } \\
\text { E.g. Materna et al. (1992), Reinhardt, T. E. and Ottmar, R. } \\
\text { D., (2004). }\end{array}$ \\
\hline
\end{tabular}

\section{Environmental impacts}

Background

- Consequences of fires suppression on the environment is an increasing concern

jectives

- Environmental effect of suppressing those fires

\begin{tabular}{|c|c|c|}
\hline Documents & \multicolumn{2}{|l|}{ Summary } \\
\hline 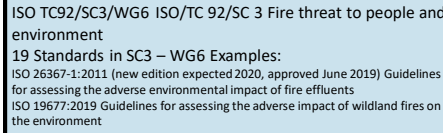 & \multicolumn{2}{|c|}{$\begin{array}{l}\text { Standards and Technical Reports } \\
\text { outlining methods to assess the } \\
\text { environmental impact of fires }\end{array}$} \\
\hline $\begin{array}{l}\text { Martin D., Tomida M., Meacham B. (2016) Environmental } \\
\text { Impact of Fire, Fire Science Reviews. }\end{array}$ & \multicolumn{2}{|c|}{$\begin{array}{l}\text { Review of current work and presentation of } \\
\text { framework to quantify environmental } \\
\text { impacts of fire (including large outdoor fires) }\end{array}$} \\
\hline $\begin{array}{l}\text { Amon F., Gehandler J., } \\
\text { McNamee R., McNamee M., } \\
\text { Vilic A. (2019) Measuring the } \\
\text { impact of fire on the } \\
\text { environment (Fire Impact } \\
\text { Tool, version 1) }\end{array}$ & $\Rightarrow$ & $\begin{array}{l}\text { Methodology (excel based) } \\
\text { to determine the } \\
\text { environmental impact of } \\
\text { selected tactical choices in } \\
\text { firefighting }\end{array}$ \\
\hline
\end{tabular}

\section{Protection of fire fighters - Health}

Background

- The impact of large outdoor fires smoke

on health is an increasing concern

Objectives

- Better understanding of smoke contents and smoke dispersion to inform potentia human exposure (for people at risk).

Consider smoke impact for fire

suppression strategies and for fires in

different environments (e.g. forest, grass,

peat, urban interfa

- Other health effects (fatigue,...)

How?

Step 1 Develop a repository presenting a summary of knowledge on smoke exposure and health impact on fire fighters in

different scenarios (urban fires, wildfires, WUI fires, prescribed burning).

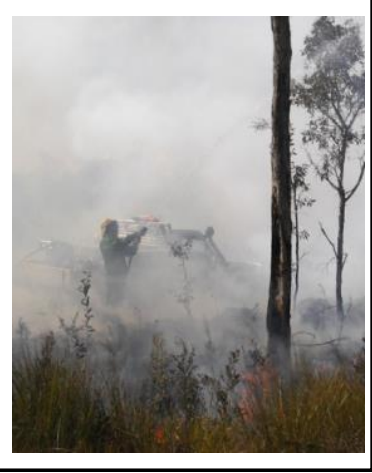

\begin{tabular}{|c|c|c|}
\hline \multicolumn{3}{|c|}{ Progress health - smoke exposure (continued) } \\
\hline Type of fires & $\begin{array}{l}\text { Smoke exposure and } \\
\text { health effect }\end{array}$ & Document/ Studies examples \\
\hline Urban fires & $\begin{array}{l}\text { Smoke exposure : urban fuels } \\
\text { Pollutants of concerns: } \\
\text { Co, formaldehyde, acrolein, } \\
\text { hydrogen chloride, hydrogen } \\
\text { cyanide (HCN), hydrogen } \\
\text { suluphide, hydrogen fluoride, } \\
\text { benzene, nitrogen dioxide, } \\
\text { sulphur dioxide and polycyclic } \\
\text { aromatic hydrocarbons (PAHs) } \\
\text { Health effects: } \\
\rightarrow \text { Short term } \\
\rightarrow \text { Long term effect }\end{array}$ & 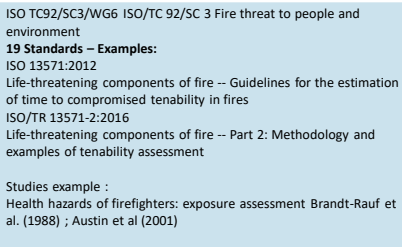 \\
\hline & $\begin{array}{l}\text { Smoke exposure: } \\
\text { - Mix natural and synthetics fuel } \\
\text { such as wildland, combustible } \\
\text { moterial from structure, house } \\
\text { contents, vehicles } \\
\text { Health effects: } \\
\rightarrow \text { Short term } \\
\rightarrow \text { Long term effect }\end{array}$ & $\begin{array}{l}\text { Australia: } \\
\text { Emissions from the combustion of major material presents in and } \\
\text { around houses: } \\
\text { E.g. Reisen, F. (2011); Reisen, F., Bhujel, M., \& Leonard, J. (2014) } \\
\text { Assessment fire exposures to the complex mixture of toxic air } \\
\text { pollutants at the ruralarbanin interface and the likely health risks: } \\
\text { Borgas, M. S., \& Reisen, F. (2013) }\end{array}$ \\
\hline
\end{tabular}

\section{Future direction}

- Collecting information

- Summary of knowledge on:

- PPE

- Crew Protection System

- Smoke exposure and health impact on firefighters

- Environmental impacts

- Other topics to include (Fire fighting tactics, Various firefighting tactics are used globally to respond to large outdoor fires

(wildfires, structure fires or fires that have reached the WUI, Incident commandment system, communication....)? 


\section{Thank you}

Acknowledgement: we would like to thank all the LOFF members for their participation. A special thank you to Margaret McNamee and Fabienne Reisen for their help with the presentation

Sara McAllister/Raphaele Blanchi

e raphaele.blanchi@csiro.au
sara.mcallister@usda.gov

w www.csiro.au

LAND \&WATER 
IGNITION RESISTANT COMMUNITIES - IRC

Elsa Pastor

Universitat Politècnica de Catalunya

Royal Halloway

June 30, 2019
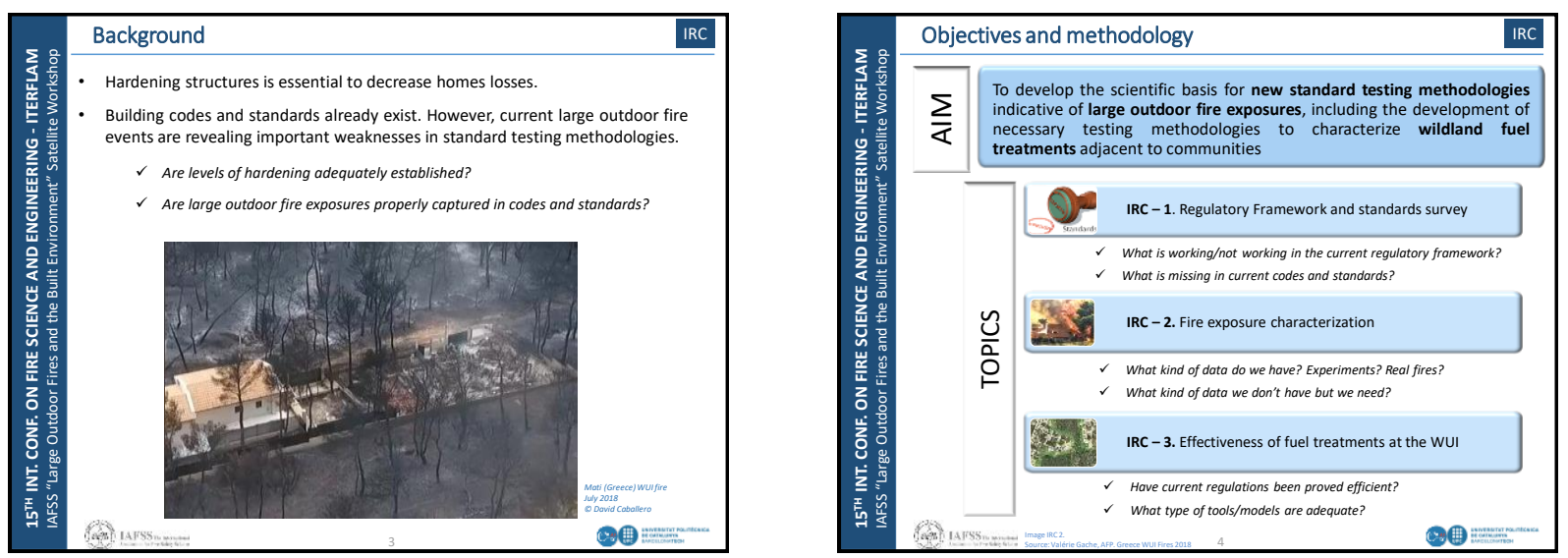

Outline

1. Background

2. Objectives and methodology

3. Work progress
$\checkmark$ Standards
$\checkmark$ Fire exposure
$\checkmark \quad$ Fuel treatments

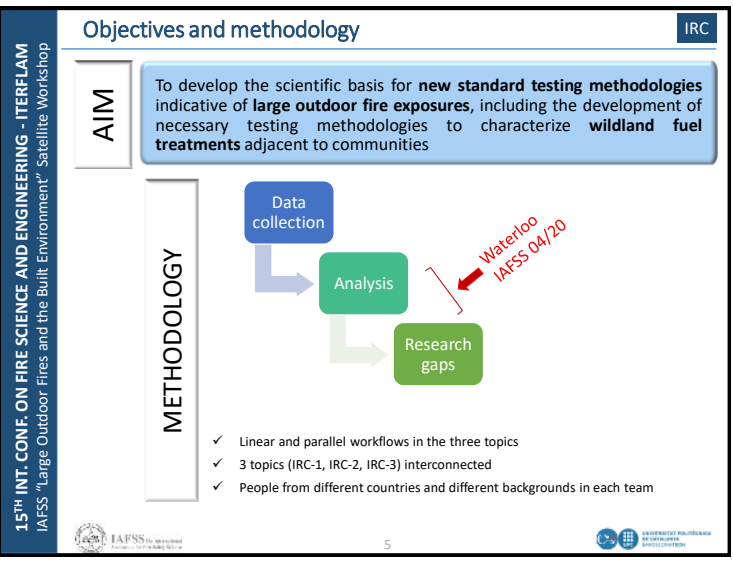

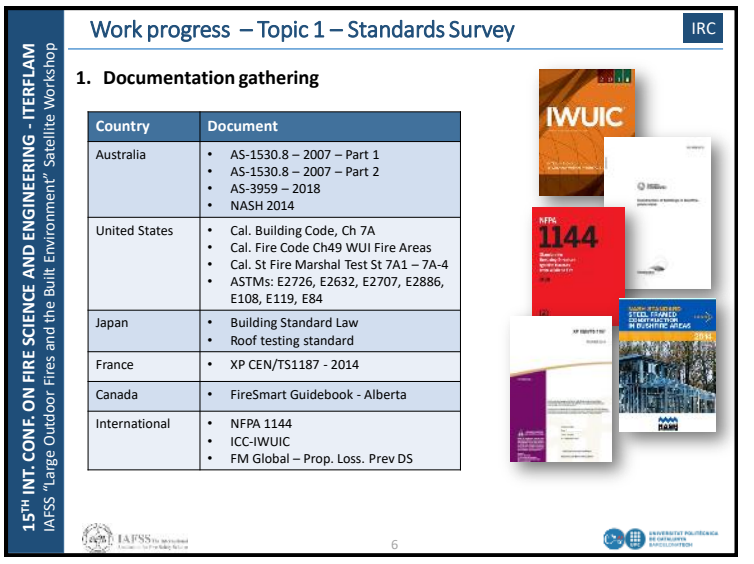



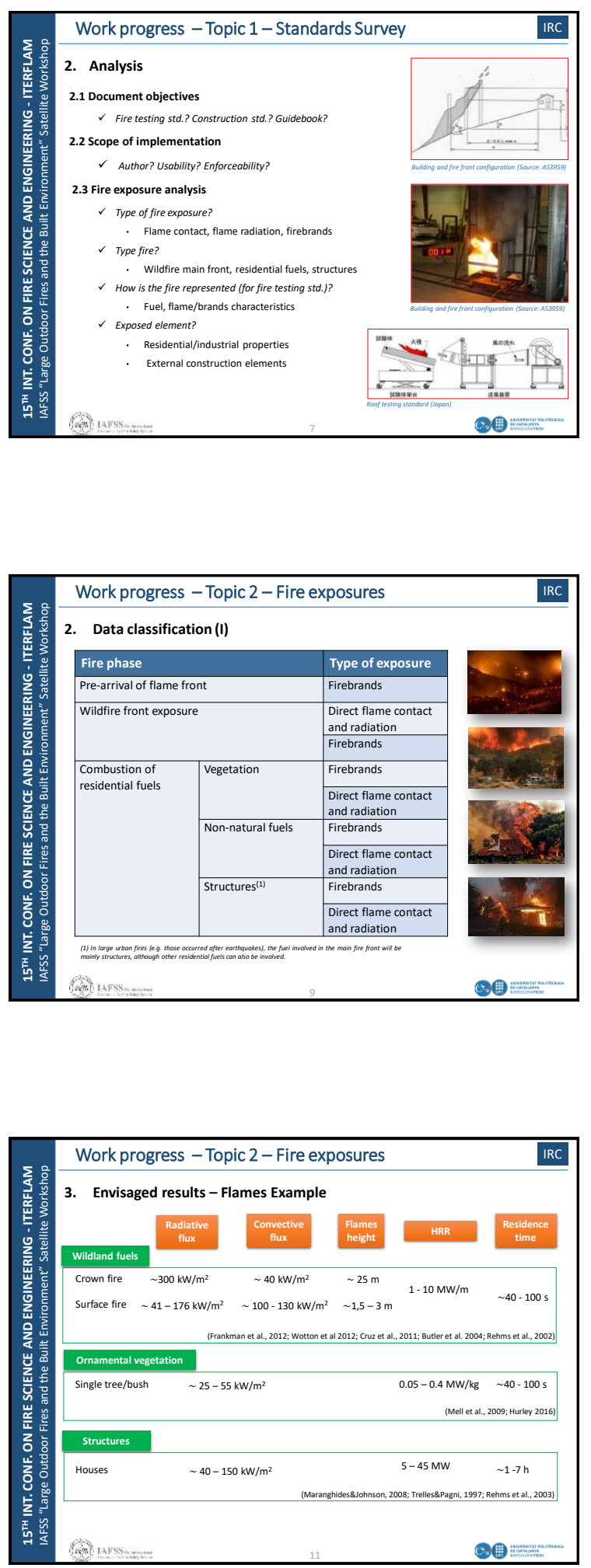
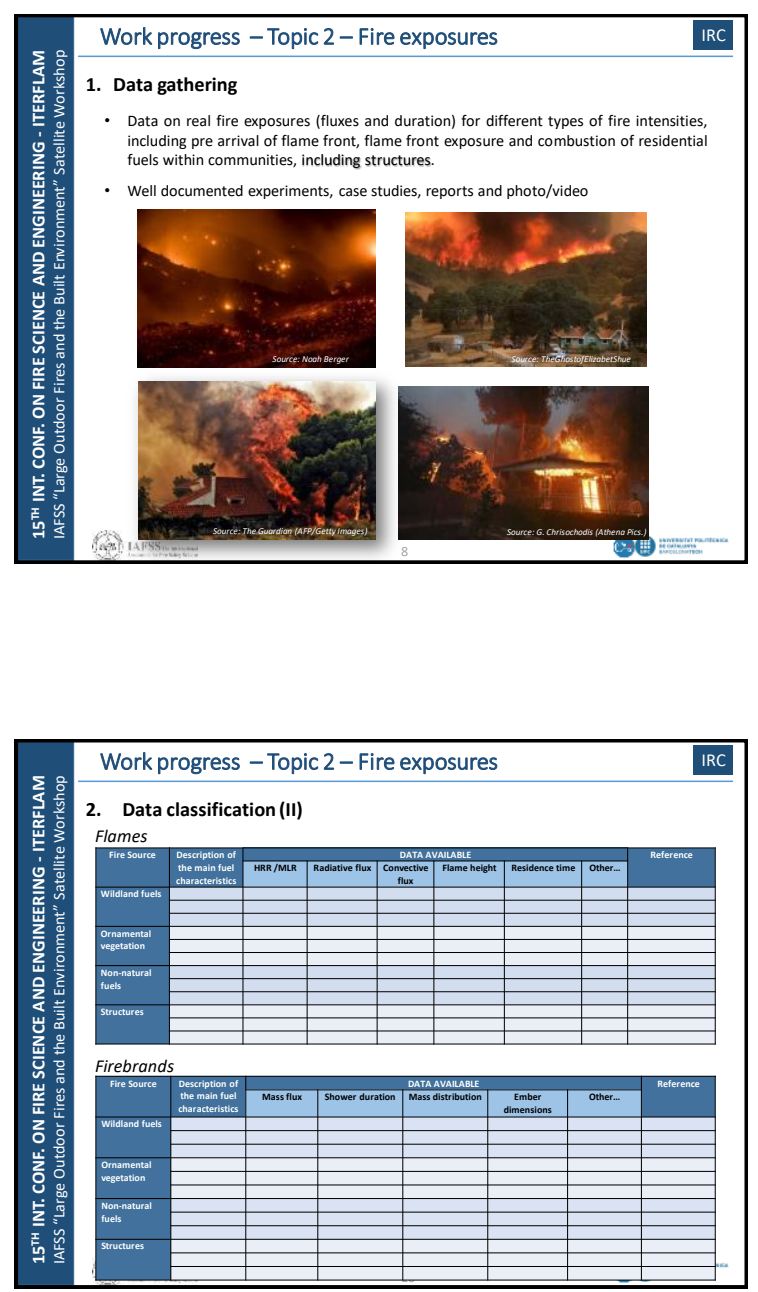

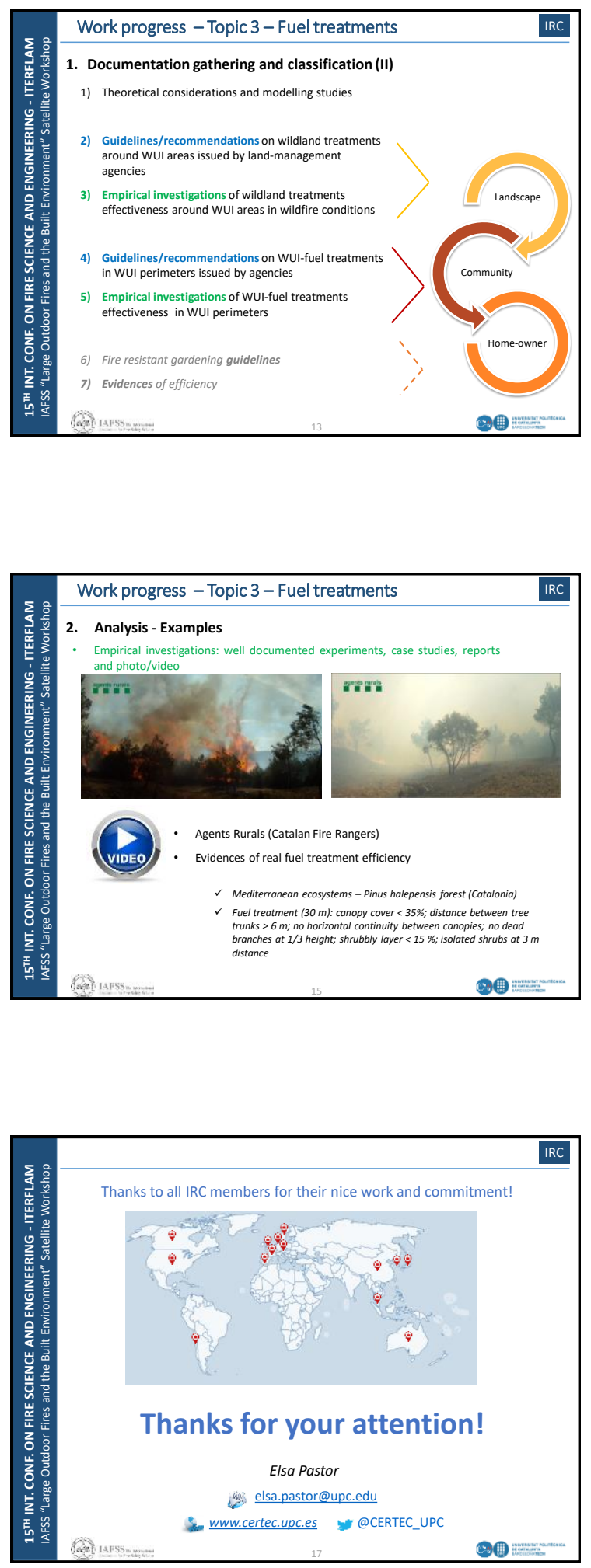

Work progress - Topic 3 - Fuel treatments

2. Analysis

Reports, guidelines, recommendations, leaflets on fuel treatments

$\checkmark$ Type of document?

$\checkmark$ country?

$\checkmark$ Type of fuel structure/ecosystem to be treated?

Fuel treatment description and scale? (Far wildland, wildland surrounding communities, perimeter fringe, etc.)

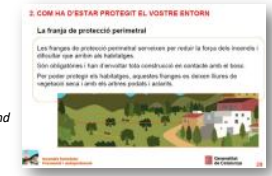

Empirical investigations: well documented experiments, case studies, reports and photo/video

$\checkmark$ Type of ecosystem and fuel structure

$\checkmark$ Fire weather

$\checkmark$ Fuel treatment

$\checkmark$ Fire behaviour descriptors

$\checkmark$ Efficiency indicators

Geit inss

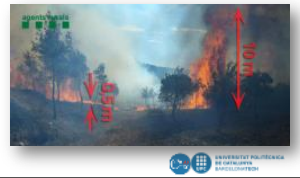

Work progress - Topic 3 - Fuel treatments

2. Analysis - Examples

Empirical investigations: well documented experiments, case studies, reports and photo/video

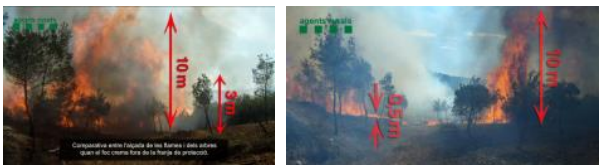

$\checkmark$ Mediterranean ecosystems - Pinus halepensis forest (Catalonia)

Fuel treatment: canopy cover <35; distance between tree trunks $>6 \mathrm{~m}$; $1 / 3$ height: shrubbly layer $<15 \%$; isolated

Fire be hoviour descriptors: flome heid

Efficiency indicators: flame height reduction: 20 times

art tarss 
Large outdoor fires and the Built Environment $\underset{\text { UNIVERSIIY }}{\text { LUND }}$

IAFSS group Workshop at Interflam 2019

\section{Emergency Management and}

Evacuation sub-group updates

\section{ENRICO RONCHI, PhD}

Associate Professor

Department of Fire Safety Engineering

Lund University, Sweden

enrico.ronchi@brand.lth.se

\section{Background}

Why an emergency management and evacuation sub-group?

Investigate strategies used around the world for emergency management in case of large outdoor fires

\section{Key issues}

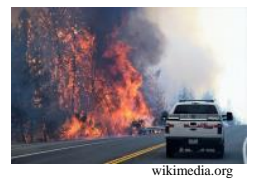

- Evacuation vs stay and defend

- Different locations (e.g., WUI, city, informal settlements, etc.)

- Different populations (e.g., number, cultural issues, history of fires, etc.)

- Local/global conditions/variables

\section{Overall EMEvac activities}

\section{Understanding of the problem}

- Literature review (ongoing)

- Development of standard templates for analysis (ongoing)

- Review of case studies (ongoing)

\section{Analysis of the problem}

- Inventory of strategies/regulatory frameworks (planned)

- Inventory of tools (planned)

- Gaps, research roadmap, assessment of strategies/tools (planned)

\section{Case studies}

Issues that have been identified

-Inconsistencies in reported information

- Reliability of sources (e.g. news, etc.)

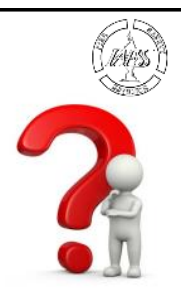

-Variability in evacuation scenarios (WUI fires, city fires, informal settlement fires, etc.)

-Difficult to retrieve information

- Need for an overview on evacuation cases worldwide

\section{Ongoing literature review}

We want to understand what we know

\section{(and what we do not know)}

Collecting available literature. Sorted by

1) Data/Survey/Interviews [19 papers]

2) Evacuation modelling [29 papers]

3) $\mathrm{HB}$ and recommendations [17 papers]

4) Non-fire relevant lit [19 papers]

5) Case studies (to be developed)

If you are aware of relevant material, please join us!

\section{Case studies}

\section{Solution}

-Standard template for the review of cases worldwide to ensure consistency (modified version based on earlier work by Ronchi et al, 2017)

- Ongoing work to build a database on LOF\&BE evacuation scenarios

- Peer review each other cases

-Members' participation to help building this up

Ronchi, E., Rein, G., Gwynne, S., Wadhwani, R., Intini, P., \& Bergstedt, A. (2017). e-Sanctuary: Open Multi-Physics Framework for Modelling Wildfire Urban Evacuation. Quincy, MA (USA): Fire Protection Research Foundation 

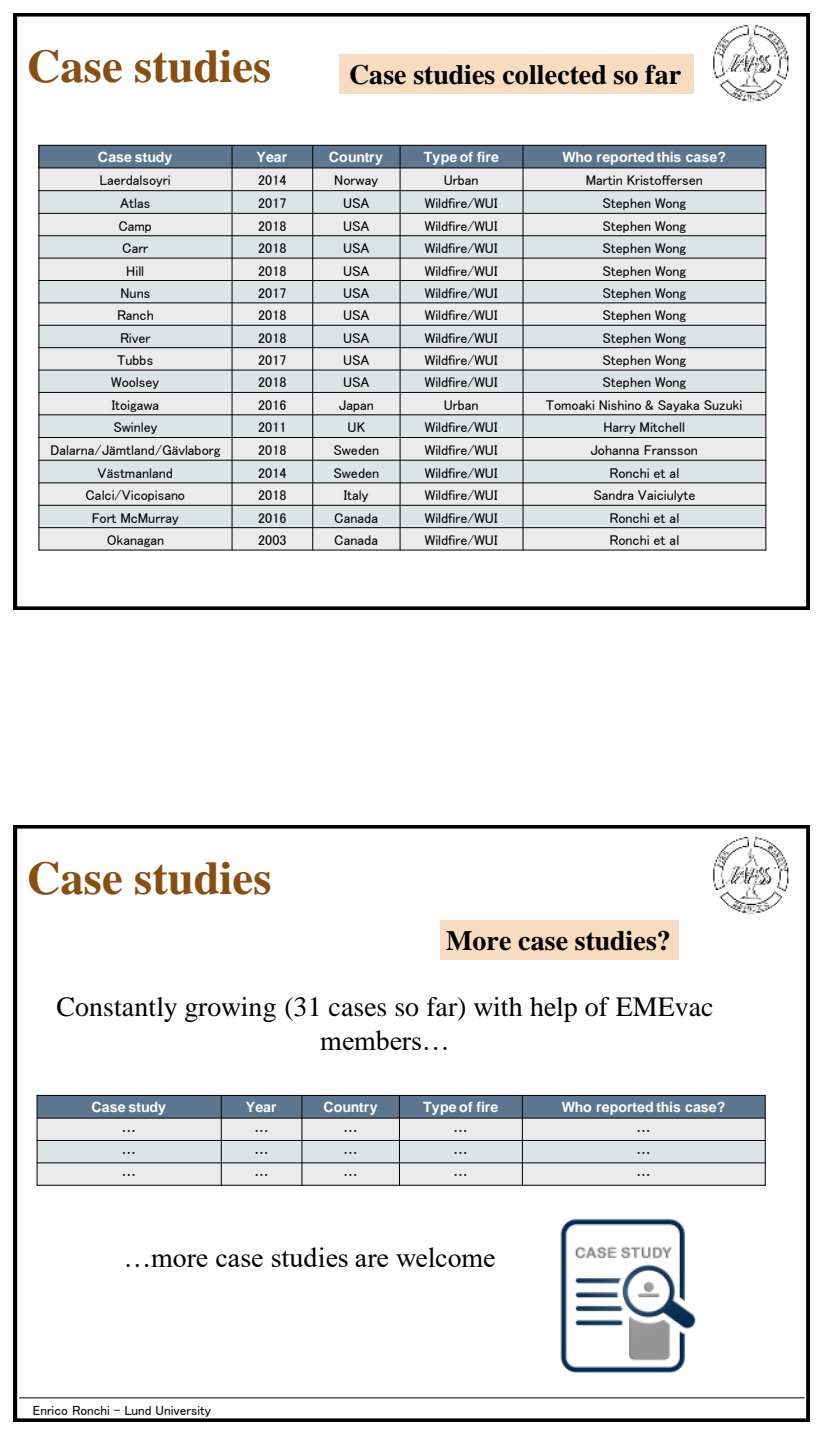

Next steps for IAFSS2020

-Proceed with case study database building

-Provide an overview on the case studies reviewed

-Template development for other issues (e.g. model reviews, evacuation strategies/regulatory issues)

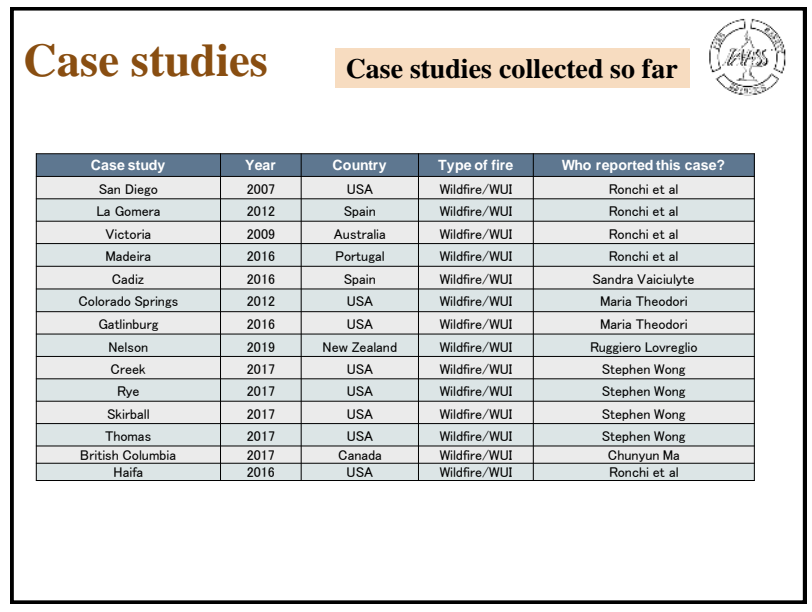

\section{Case studies}

Goal

- Build a broad knowledge on LOF\&BE evacuation cases worldwide

- Collect a constantly growing number of cases

- Expand the number of scenarios (e.g. informal settlements, unconventional evacuation means)

- Expand number of regions covered

- Improve the template (log of comments of people filling in the template)

- Have a living database of the EMEvac group that can grow and improve over time

\section{Further long term goals}

- Build a research roadmap on EMEvac based on consolidated knowledge

- Development of test case scenario(s) to evaluate the capabilities and limitations of existing tools to aid emergency management

- Enhancement of accessibility of existing and future evacuation data-sets

- Summary of inventory of existing tools for aiding emergency management 


\section{THANK YOU!}

Email: enrico.ronchi@brand.lth.se 